\title{
Pengaruh Media pada Karakter Biokimia dan Keberhasilan Pencangkokan Tanaman Teh (Camellia sinensis L. (O.) Kuntze) pada Klon TRI 2025
}

\section{(Effect of Media on Biochemical Characteristics and Success of Tea (Camelia sinensis L. (O.) Kuntze) Plant Transplantation in TRI 2025 Clone)}

\author{
Ika Betty Widyastuti ${ }^{\star *}$, Prapto Yudono ${ }^{2}$, Eka Tarwaca Susila Putra ${ }^{2}$ \\ (Diterima Januari 2020/Disetujui Desember 2020)
}

\begin{abstract}
ABSTRAK
Banyaknya tanaman teh yang tua, rusak, atau mati menyebabkan populasi tanaman per hektar menjadi rendah sehingga produktivitas menurun. Perbanyakan dengan teknik cangkok digunakan untuk menyulam karena memiliki keunggulan masa TBM yang lebih singkat dan ukuran bibit yang lebih tinggi sehingga dapat mengimbangi tanaman di sekitarnya, namun kelemahan mencangkok ialah tingkat keberhasilan yang rendah. Penelitian ini bertujuan untuk 1) mengetahui perubahan morfologis akar cangkok dan biokimia cangkokan pada klon TRI 2025 yang dicangkok menggunakan media serbuk sabut kelapa, arang sekam, dan moss, 2) menentukan tingkat keberhasilan pencangkokan pada setiap media. Penelitian ini dilaksanakan pada bulan Agustus 2018-Januari 2019 di kebun produksi Pagilaran, PT. Pagilaran, Batang, Jawa Tengah. Percobaan lapangan disusun menggunakan Rancangan Lingkungan Acak Lengkap (RAL) faktor tunggal. Faktor yang diuji adalah macam media cangkok, yaitu media arang sekam, serbuk sabut kelapa, dan moss. Pengamatan dilakukan pada morfologis akar cangkok, kadar glukosa, sukrosa, dan gula total pada kulit batang yang dicangkok serta konsentrasi hormon auksin, giberelin, dan sitokinin pada akar cangkok. Data yang diperoleh selanjutnya dianalisis menggunakan sidik ragam dan apabila terdapat beda nyata antarperlakuan dilanjutkan dengan uji jarak berganda Duncan (DMRT) pada tingkat kepercayaan $95 \%$. Hasil penelitian menunjukkan bahwa jenis media tidak berpengaruh nyata pada kemampuan membentuk glukosa, sukrosa, dan gula total pada kulit batang. Perkembangan morfologis akar cangkok media serbuk sabut kelapa secara nyata terlihat paling tinggi. Nisbah sitokinin/auksin pada serbuk sabut kelapa ditemukan paling rendah, tetapi kadar tertinggi sitokinin dan auksin ditemukan pada moss, sedangkan serbuk sabut kelapa mempunyai kadar giberelin tertinggi. Tingkat keberhasilan pencangkokan tertinggi adalah pada moss, yaitu sebesar $58,33 \%$, sedangkan serbuk sabut kelapa dan arang sekam memiliki tingkat keberhasilan yang sama dan lebih rendah, yaitu sebesar $41,60 \%$.
\end{abstract}

Kata kunci: biokimia, cangkok, keberhasilan, media, TRI 2025

\section{ABSTRACT}

The large number of old, damaged, or dead tea plants cause the plant population per hectare to be low that eventually decreases the productivity. Propagation using the transplantation technique is used for embroidery because it has the advantage of a shorter immature plant period and higher seed size so that it can compensate for the surrounding plants but the weakness of transplantation is low success rate. This study aims to 1) determine the morphological changes of root transplantation and biochemistry on TRI 2025 clone transplantation using cocopeat, husk charcoal, and moss, 2) determine the success rate of transplantation in each medium. This research was conducted in August 2018-January 2019 at the Pagilaran production garden, PT. Pagilaran, Batang, Central Java. Field experiments were prepared using a single factor Completely Randomized Environment Design (CRD). The factors tested were the type of transplantation media, namely the media of husk charcoal, cocopeat, and moss. Observations were made on transplantation root morphology, levels of glucose, sucrose, and total sugar in the transplanted stem bark and the concentration of auxin, gibberellin, and cytokinin in the transplant roots. The data obtained were then analyzed using variance and if there was a significant difference between treatments, the Duncan multiple distance test (DMRT) was continued at the $95 \%$ confidence level. The results showed that the type of media had no significant effect on the ability to form glucose, sucrose, and total sugar in the bark. The development of root morphology of cocopeat media was seen to be the highest. The ratio of cytokinin/auxin in cocopeat was the lowest but the highest levels of cytokinin and auxin were found in moss, while cocopeat had the highest level of gibberellin. The highest transplanting success rate was found in moss medium with $58.33 \%$, cocopeat and husk charcoal media had the same success rate, namely $41.60 \%$.

Keywords: transplantation, biochemistry, media, success, TRI 2025

\footnotetext{
Staff Direktorat Perbenihan Perkebunan, Direktorat Jenderal Perkebunan, Kementerian Pertanian Gedung C Jl. RM. Harsono, Ragunan, Kota Jakarta Selatan 12550

2 Jurusan Agronomi, Fakultas Pertanian, Universitas Gadjah Mada, Jl. Flora, Bulaksumur, Yogyakarta 55281

* Penulis Koresponednsi: Email: ikabetty.ib@gmail.com
}

\section{PENDAHULUAN}

Tanaman teh (Camellia sinensis (L.) O. Kuntze) merupakan salah satu tanaman komoditas utama perkebunan. Teh memiliki peranan tidak hanya dalam 
aspek ekonomi, tetapi juga dalam aspek sosiologi, ekologi, dan geografi, di antaranya sebagai penghasil devisa negara, sumber pendapatan petani, penciptaan lapangan kerja, mendorong agroindustri, pengembangan wilayah, serta pelestarian lingkungan. Agroindustri teh Indonesia mengalami penurunan karena berbagai masalah yang belum dapat diatasi, seperti produktivitas tanaman yang rendah karena dominasi tanaman teh rakyat yang belum menggunakan benih unggul, penguasaan teknologi pengolahan produk yang terbatas, dan keadaan petani yang belum mampu mengikuti teknologi yang telah direkomendasikan (Good Agriculture Practice/GAP dan Good Manufacture Process/GMP) standar kualitas produk sebagaimana disyaratkan oleh ISO (Kementerian Pertanian 2014). Lingkaran permasalahan pertehan nasional dimulai dari kebun yang tidak dipelihara dengan baik yang kemudian menyebabkan produktivitas yang rendah, biaya produksi yang tinggi, dan menghasilkan teh yang bermutu rendah sehingga harga jual rendah. Identifikasi lapangan menunjukkan bahwa kondisi tanaman teh di perkebunan teh sekitar $60 \%$ merupakan tanaman tua/rusak, produktivitas rendah yang hanya $50 \%$ dari potensi produksi, mesin pengolahan yang telah tua dan tidak memenuhi standar GMP/ISO/SNI, serta biaya produksi yang mengalami kenaikan > 10\%/tahun, sedangkan harga jual hanya naik $\pm 4 \%$ /tahun (Arifin 2014).

Terdapat peluang penggunaan inovasi untuk melakukan perbanyakan teh dengan teknik cangkok dengan memanfaatkan sebagian limbah cabangcabang yang terbuang dalam kegiatan pangkas bersih yang rutin dilakukan pada perkebunan teh. Uji coba yang pernah dilakukan pekebun menunjukkan bahwa perbanyakan tanaman teh dengan teknik cangkok dapat mempersingkat masa Tanaman Belum Menghasilkan (TBM) menjadi $\pm 1,5$ tahun dibandingkan dengan bibit asal setek yang memiliki masa TBM 4 tahun (Mumpuni 2008). Berbeda dari perbanyakan setek daun, bibit cangkokan sudah berupa tanaman dewasa serta sudah memiliki percabangan (frame) yang cukup sempurna dengan kerangka percabangan, batang berkayu, dan daun-daun. Oleh karena itu, bibit cangkokan cukup sesuai untuk dipergunakan dalam program pemadatan populasi (infilling) yang memiliki persyaratan berbeda dari persyaratan bibit untuk program penanaman baru (new planting) maupun replanting. Bibit cangkokan cukup ideal untuk digunakan dalam program menyulam/mengganti tanaman yang telah tua, rusak, atau mati. Pada perbanyakan vegetatif, setek, klon teh, dan media tanam berpengaruh sangat nyata pada persentase setek hidup, persentase setek bertunas dan berakar, panjang tunas, jumlah daun, jumlah akar, panjang akar, dan bobot akar (Mahfudloh 2008). Pada perbanyakan teknik cangkok, keberhasilan pencangkokan dipengaruhi oleh 2 faktor, yaitu internal dan eksternal. Yang termasuk faktor internal adalah hereditas (gen) dan hormon. Secara fisiologis, hormon tumbuhan sebagai penyampai pesan antarsel yang dibutuhkan untuk mengontrol semua daur hidup tumbuhan, di antaranya perkecambahan, perakaran, pertumbuhan, pembungaan, dan pembuahan. Hormon berperan dalam mengendalikan aktivitas gen (Salisbury \& Ross 1995). Faktor eksternal adalah lingkungan. Pencangkokan dilakukan dalam satu hamparan dengan kondisi lingkungan yang seragam sehingga faktor eksternal yang diujikan adalah jenis media, yaitu arang sekam, serbuk sabut kelapa, dan moss yang memengaruhi pembentukan akar cangkok.

Klon TRI 2025 merupakan klon unggul lama yang memiliki keunggulan yang tahan terhadap kekeringan. Klon ini banyak terdapat di perkebunan-perkebunan teh di Indonesia. Klon TRI 2025 mampu menghasilkan teh sebanyak $3.000 \mathrm{~kg}$ teh kering/ha/thn dengan produktivitas rata-rata $2.000 \mathrm{~kg}$ teh kering. Pada tanaman teh, bobot $p+2$ dapat digunakan untuk menilai stabilitas genotipe tanaman pada berbagai lingkungan. Menurut Mangoendidjojo (1993), klon TRI 2025 mempunyai stabilitas hasil yang baik, diikuti klon Cin 143, dan TRI 2024. Hasil penelitian Martono \& Wicaksono (2020) menunjukkan bahwa genotipe berpengaruh pada penampilan karakter panjang peko, panjang daun, lebar daun, panjang tangkai daun, bobot $p+2$, bobot $p+3$, panjang ruas daun, dan produksi pucuk segar.

Media yang digunakan untuk mencangkok adalah media yang bersifat remah dan ringan. Arang sekam dan serbuk sabut kelapa merupakan bahan organik yang mudah diperoleh karena merupakan produk hasil sampingan padi dan kelapa. Kelebihan arang sekam sebagai media tanam karena bersifat porus, ringan, tidak kotor, dan dapat menahan air. Arang sekam juga memiliki $\mathrm{pH}$ yang cukup netral sehingga ramah terhadap lingkungan. Kelebihan serbuk sabut kelapa sebagai media tanam karena karakteristiknya yang mampu mengikat dan menyimpan air dengan sangat kuat sehingga sesuai dan cocok digunakan untuk daerah panas atau yang kesulitan air (Miranda 2017), sedangkan moss merupakan sejenis lumut. Moss memiliki sifat ringan, tidak kotor, dan dapat menahan air dalam jangka waktu lama, namun tidak becek. Air disimpan di dalam sel yang mati, terutama di daundaunnya. Air diikat kuat sehingga meskipun terkena angin ataupun panas matahari tidak akan mengering.

Permasalahan pembibitan menggunakan metode cangkok dengan media tanah pada tanaman teh selama ini banyak mengalami kegagalan karena akar cangkok tidak tumbuh atau akar dapat tumbuh, tetapi memerlukan waktu sangat lama \pm 8 bulan. Keberhasilan pencangkokan tanaman teh dengan media tanah memiliki tingkat keberhasilan yang rendah. Hal ini dapat disebabkan karena tanah sebagai media cangkok memiliki sifat mudah mengeras/struktur mampat sehingga tidak terdapat ruang seimbang antara udara dan air. Melalui penelitian pencangkokan dengan media serbuk sabut kelapa, arang sekam, dan moss ini diharapkan dapat memperoleh informasi 
tentang media cangkok yang paling tepat yang dapat mendukung keberhasilan pencangkokan tanaman teh.

\section{METODE PENELITIAN}

\section{Tempat dan Waktu}

Penelitian cangkok pada tanaman teh dilakukan di kebun produksi PT. Pagilaran, Batang, Jawa Tengah, di salah satu petak blok Sijenggel. Penelitian dilaksanakan selama \pm 5 bulan, yaitu pada akhir bulan Agustus 2018-2 Januari 2019. Analisis hormon auksin, sitokinin, dan giberelin dilakukan di laboratorium Residu Bahan Agrokimia, Bogor dengan metode HPLC. Sementara itu, analisis sukrosa, glukosa, dan gula total dilakukan di laboratorium Hortikultura dan pengamatan morfologi akar cangkok (panjang dan luas permukaan) dilakukan di laboratorium Fisiologi Tanaman, Fakultas Pertanian UGM.

\section{Bahan dan Alat Utama}

Bahan yang digunakan dalam penelitian ini adalah 1) Cabang tanaman teh klon TRI 2025 berdiameter 3$5 \mathrm{~cm}$, yang merupakan ukuran cabang rata-rata di petak tersebut. Tidak terdapat diameter cabang yang lebih kecil. Umur tanaman adalah 11 tahun (tanam tahun 2009) dan 2) Media cangkok ialah serbuk sabut kelapa, arang sekam, dan moss.

Alat yang digunakan adalah 1) Peralatan untuk mencangkok, gunting, pisau, plastik bening pembungkus media, plastik kresek hitam, tali rafia, cooler box, dan ice gel dan 2) Peralatan laboratorium adalah HPLC, tabung reaksi, erlenmeyer.

\section{Rancangan Percobaan}

Percobaan lapangan disusun menggunakan Rancangan Acak Lengkap (RAL) faktor tunggal dengan 3 ulangan untuk masing-masing perlakuan. Faktor yang diuji adalah macam media cangkok. Percobaan pengujian macam media cangkok ini menggunakan perdu teh klon TRI 2025.

Macam media cangkok yang diuji pada penelitian ini ada tiga, yaitu 1) arang sekam, 2) serbuk sabut kelapa, dan 3) moss. Masing-masing perlakuan macam media cangkok diuji menggunakan 3 perdu tanaman induk. Masing-masing perdu dicangkok sebanyak dua cabang sehingga per perdu terdapat dua calon bibit asal cangkok.

\section{Metode Penelitian}

Dipilih tanaman yang sehat, pertumbuhan dan produksi yang baik serta akan dilakukan pemangkasan karena tujuan pencangkokan adalah memanfaatkan limbah pangkasan untuk menyulam tanaman yang telah tua, rusak, atau mati. Pada percobaan ini dipilih tanaman TP 4 yang sebulan lagi direncanakan akan dilakukan pemangkasan bersih. Sebelumnya dilakukan uji kadar pati akar dengan yodium berwarna biru tua yang menandakan kadar pati akar > 12\%. Dilakukan analisis kadar pati akar dengan metode yodium diteteskan pada akar. Jika berwarna biru tua maka tanaman memiliki kadar pati akar yang mencukupi untuk dilakukan pencangkokan.

Dilakukan analisis awal kadar hormon auksin pada kulit cabang yang akan dicangkok. Cabang dikerat sepanjang $\pm 10 \mathrm{~cm}$ dan dibersihkan kulit batang serta kambiumnya sampai bersih. Didiamkan 2 hari hingga kambium kering. Luka sayatan dibalut dengan media yang telah dipersiapkan dalam kantong plastik bening yang diberi lubang pada bagian bawahnya, dengan jumlah lubang yang cukup untuk mengeluarkan air pada saat jumlah air berlebih. Media ini telah dibasahi air hingga kapasitas lapang. Panjang plastik $>10 \mathrm{~cm}$, agar dapat menutup luka sayatan cangkok. Bobot masing-masing media dalam plastik $\pm 0,5 \mathrm{~kg}$. Plastik disobek memanjang dan ditangkupkan pada luka sayatan.

Kedua ujung plastik yang menutup sayatan diikat kuat dengan tali rafia agar tidak mudah bergeser. Diusahakan luka sayatan tertutup seluruhnya dengan media, terutama sayatan sebelah atas karena di tempat itulah akan tumbuh akar. Cangkokan ditutup dengan plastik kresek hitam agar terhindar dari cahaya, dan hal ini bertujuan supaya cangkokan lebih cepat berakar. Dilakukan pemeriksaan setiap minggu pada kondisi cangkokan dan disiram apabila media kering.

\section{HASIL DAN PEMBAHASAN}

Sebelum pencangkokan, dilakukan analisis awal (Tabel 1) untuk mengetahui kadar sukrosa, glukosa, dan gula total awal serta kadar hormon auksin, sitokinin, giberelin. Kadar auksin endogen pada tanaman sebelum dicangkok adalah $2,13 \times 10^{-8} \mathrm{M}$. Menurut Salisbury \& Ross (1995), kadar auksin dapat memacu pemanjangan akar apabila auksin dalam konsentrasi yang sangat rendah, yaitu antara $10^{-7}$ sampai $10^{-13} \mathrm{M}$. Pada konsentrasi yang lebih tinggi, tapi masih cukup rendah antara 1-10 $\mu \mathrm{M}$, pemanjangan hampir selalu terhambat.

Untuk mempercepat kerja auksin menumbuhkan akar cangkok, digunakan plastik hitam untuk menutup cangkokan. Auksin pada tanaman yang terkena

Tabel 1 Kadar beberapa jenis gula dan hormone tumbuh pada kulit batang tanaman teh sebelum dicangkok

\begin{tabular}{lccccccc}
\hline Analisis & $\begin{array}{c}\text { Glukosa kulit } \\
\text { batang } \\
(\%)\end{array}$ & $\begin{array}{c}\text { Sukrosa } \\
\text { kulit } \\
\text { batang } \\
(\%)\end{array}$ & $\begin{array}{c}\text { Gula total } \\
\text { kulit } \\
\text { batang } \\
(\%)\end{array}$ & $\begin{array}{c}\text { Auksin } \\
\text { kulit } \\
\text { batang } \\
(\mathrm{M})\end{array}$ & $\begin{array}{c}\text { Giberelin } \\
\text { kulit } \\
\text { batang } \\
(\mathrm{M})\end{array}$ & $\begin{array}{c}\text { Sitokinin kulit } \\
\text { batang } \\
(\mathrm{M})\end{array}$ & $\begin{array}{c}\text { Nisbah } \\
\text { sitokinin/ } \\
\text { auksin }\end{array}$ \\
\hline Kadar & 0,107 & 0,49 & 0,59 & $2,13 \times 10^{-8}$ & $6,12 \times 10^{-9}$ & $1,56 \times 10^{-10}$ & 0,007 \\
\hline
\end{tabular}


cahaya matahari akan mengalami kerusakan dan terhambat sehingga pertumbuhan tanaman menjadi lebih lambat. Sebaliknya, tanaman yang tidak terkena cahaya matahari, pertumbuhan menjadi lebih cepat (Campbell \& Reece 2002). Sejalan dengan hal tersebut, Ashari (2006) menyatakan bahwa keadaan gelap dan lembap akan menyebabkan akar dapat tumbuh dengan cepat.

Analisis setelah pencangkokan menunjukkan kadar sukrosa, glukosa, dan gula total pada kulit cabang yang dicangkok tidak menunjukkan perbedaan yang nyata pada ketiga media (Tabel 2). Demikian pula dengan analisis kadar hormon auksin, giberelin, dan sitokinin akar cangkok tidak menunjukkan perbedaan nyata pada ketiga media (Tabel 3).

Ternyata, jenis media cangkok yang digunakan, yaitu arang sekam, serbuk sabut kelapa, dan moss tidak memengaruhi pembentukan sukrosa, glukosa, dan gula total pada batang yang dicangkok tersebut. Pembentukan akar pada cangkok terjadi karena penumpukan zat-zat makanan yang berasal dari daundaun di bagian atas sayatan yang tidak dapat bergerak menuju bagian bawah sayatan sehingga pada bagian atas tersebut, kulit batang akan menggembung akibat penumpukan auksin dan karbohidrat. Campbell \& Reece (2002) menyatakan bahwa auksin menyebabkan pengenduran dinding sel yang mengakibatkan air dapat masuk secara osmosis. Dengan adanya media tanam akan memicu pembentukan kalus atau akar.

Karakter biokimia kadar auksin, sitokinin, dan giberelin juga tidak terpengaruh oleh penggunaan media cangkok yang berbeda. Hanya terdapat sedikit perbedaan yang tidak nyata (Gambar 1), namun moss terlihat memiliki kadar auksin dan sitokinin tertinggi, sedangkan serbuk sabut kelapa memiliki kadar giberelin tertinggi. Pembentukan akar adalah kerja sinergis beberapa hormon. Menurut Salisbury \& Ross (1995), akar juga mensintesis giberelin dan diedarkan ke tajuk melalui xylem. Giberelin tidak hanya berguna untuk pemanjangan batang saja, tetapi juga untuk pertumbuhan semua organ tumbuhan, termasuk daun dan akar.

Auksin sangat diperlukan dalam pembentukan akar dengan memacu proses pembelahan sel. Menurut Miyashita et al. (2009), kombinasi antara sitokinin dengan auksin yang tepat dapat menginduksi pembentukan kalus. Auksin tidak berfungsi dengan baik bila tidak berinteraksi dengan zat pengatur tumbuh

Tabel 2 Kadar sukrosa, glukosa, dan gula total kulit batang pada tiga jenis media

\begin{tabular}{|c|c|c|c|}
\hline Media & Sukrosa (\%) & Glukosa (\%) & Gula total (\%) \\
\hline Arang sekam & $3,81^{a}$ & $4,86^{\mathrm{a}}$ & $1,13^{\mathrm{a}}$ \\
\hline Serbuk sabut kelapa & $3,77^{a}$ & $5,22^{a}$ & $0,53^{a}$ \\
\hline Moss & $4,75^{a}$ & $5,53^{a}$ & $0,83^{a}$ \\
\hline Koefisien variasi & 12,86 & 19,81 & 18,39 \\
\hline
\end{tabular}

Keterangan: Angka-angka pada kolom sama yang diikuti huruf sama tidak berbeda nyata pada uji DMRT taraf kepercayaan $95 \%$.

Tabel 3 Kadar auksin, giberelin, dan sitokinin akar cangkok pada tiga jenis media

\begin{tabular}{lccc}
\hline \multicolumn{1}{c}{ Media } & \multicolumn{3}{c}{ Rerata } \\
\cline { 2 - 4 } & Auksin (M) & Giberelin $(\mathrm{M})$ & Sitokinin $(\mathrm{M})$ \\
\hline Arang sekam & $6,91 \times 10^{-9} \mathrm{a}$ & $3,55 \times 10^{-9} \mathrm{a}$ & $6,54 \times 10^{-11} \mathrm{a}$ \\
Serbuk sabut kelapa & $7,87 \times 10^{-9} \mathrm{a}$ & $4,74 \times 10^{-9} \mathrm{a}$ & $4,56 \times 10^{-11} \mathrm{a}$ \\
Moss & $8,51 \times 10^{-9} \mathrm{a}$ & $2,93 \times 10^{-9} \mathrm{a}$ & $8,67 \times 10^{-11} \mathrm{a}$ \\
\hline Koefisien keragaman (\%) & 16,06 & 10,72 & 11,05 \\
\hline
\end{tabular}

Keterangan: Angka-angka pada kolom sama yang diikuti huruf sama tidak berbeda nyata pada uji DMRT taraf kepercayaan $95 \%$

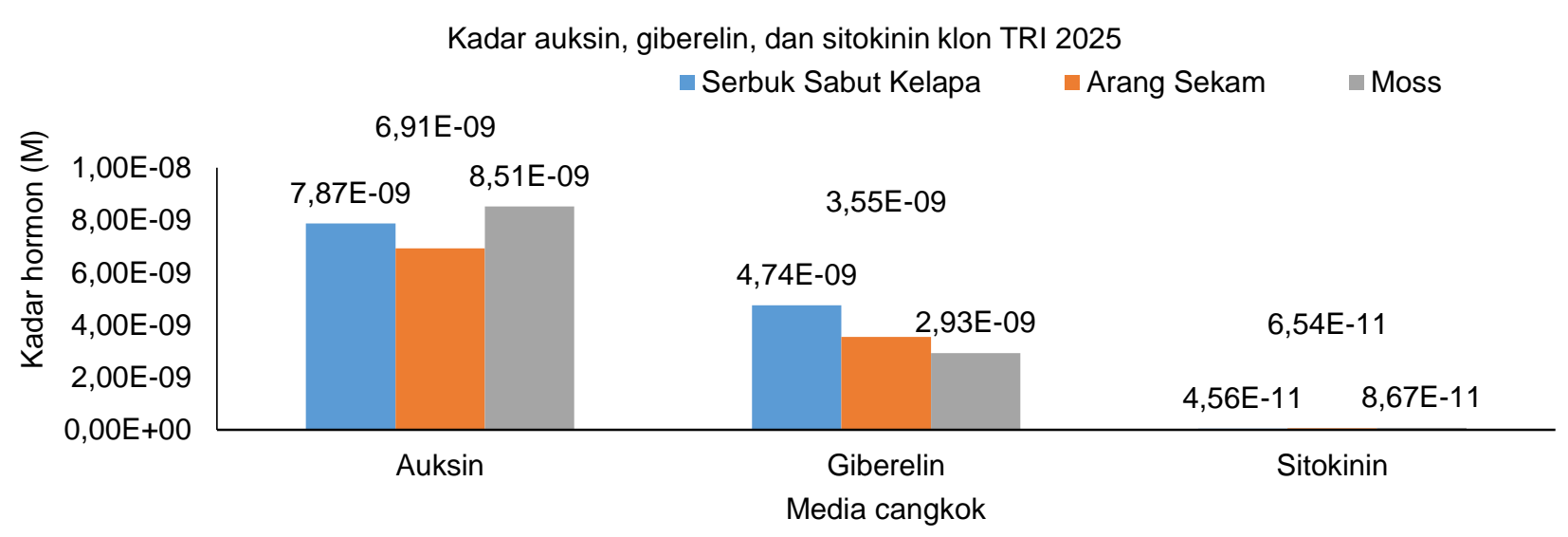

Gambar 1 Kadar auksin, sitokinin, dan giberelin pada 3 jenis media. (Sebaiknya diubah menjadi bentuk table) 
lainnya, seperti sitokinin dan nutrisi lainnya. Interaksi crosstalk auksin dan sitokinin diperlukan untuk menghasilkan dan mempertahankan pola jaringan. Auksin mengatur biosintesis sitokinin dan pensinyalan, sedangkan sitokinin mengatur transportasi auksin. Kadar sitokinin berkurang karena menekan biosintesis auksin. Fenomena ini menunjukkan regulasi positif auksin yang dimediasi oleh sitokinin (Hua Su et al. 2011). Penelitian Samudin (2009) menunjukkan bahwa penggunaan media dengan kombinasi auksin-sitokinin yang berbeda menyebabkan respons yang berbeda pada pertumbuhan buah naga. Diduga telah terjadi perimbangan antara sitokinin dan auksin sehingga terjadi pembelahan sel yang menstimulasi pembentukan tunas, duri, dan akar buah naga.

Pada ketiga media, kadar auksin > kadar sitokinin dan hal ini berarti bahwa pertumbuhan akan mengarah ke pembentukan akar. Auksin dan sitokinin pada media moss yang dominan mensyaratkan bahwa media ini akan menjadi media yang akan lebih baik untuk pertumbuhan akar cangkoknya dibandingkan dengan media lain. Hal ini terkait dengan peran auksin dan sitokinin, keduanya akan menstimulasi pembelahan sel dan memengaruhi lintasan diferensiasi. Interaksi antagonis antara auksin dan sitokinin juga merupakan salah satu cara tumbuhan dalam mengatur derajat pertumbuhan akar, misalnya jumlah akar yang banyak akan menghasilkan sitokinin dalam jumlah banyak (Widyastuti \& Donowati 2007). Nisbah sitokinin/auksin dapat dilihat pada Tabel 4.

Tabel 4 menunjukkan nisbah sitokinin/auksin terendah pada media serbuk sabut kelapa, dan hal ini berarti bahwa media serbuk sabut kelapa menjadi media tercepat dalam pembentukan akar cangkok. Perbandingan sitokinin dan auksin yang rendah akan mendorong pembentukan akar (Sulasiah et al. 2015). Kalus mulai muncul pada 4 MSC (Minggu Setelah
Cangkok) dan pada 8 MSC mulai tumbuh akar (Gambar 2).

Pengamatan morfologi akar cangkok yang mencakup panjang dan luas permukaan akar pada ketiga media menunjukkan bahwa serbuk sabut kelapa memiliki panjang dan luas permukaan akar tertinggi (Gambar 3).

Dari analisis statistik terdapat korelasi positif antara kadar auksin dan morfologi akar cangkok (Tabel 5), berarti semakin tinggi kadar auksin maka panjang dan luas permukaan akar cangkok juga akan semakin besar. Berdasarkan kadar auksin tertinggi maka pada media moss akan ditemukan pembentukan akar paling tinggi, namun kenyataannya perkembangan morfologis akar tertinggi ditemukan pada media serbuk sabut kelapa. Hal itu terjadi karena nisbah sitokinin/auksin terendah ditemukan pada media serbuk sabut kelapa sehingga media ini akan lebih cepat dalam pembentukan akar cangkok.

Perhitungan tingkat keberhasilan pencangkokan tertinggi ditemukan pada media moss dengan keberhasilan pencangkokan sebesar 58,33\%. Media arang sekam dan serbuk sabut kelapa memberikan hasil yang sama, yaitu 41,60\% (Tabel 6). Berdasarkan sifat fisik media, serbuk sabut kelapa sangat erat memegang, mengikat, dan menahan air yang menyebabkan media menjadi jenuh air karena jumlah hujan sangat tinggi sehingga media moss memberikan keberhasilan tertinggi. Moss memiliki banyak rongga sehingga memungkinkan akar tanaman tumbuh dan

Tabel 4 Nisbah sitokinin/auksin akar cangkok pada 3 jenis media

\begin{tabular}{lc}
\hline \multicolumn{1}{c}{ Media } & Sitokinin/Auksin \\
\hline Serbuk sabut kelapa & 0,006 \\
Arang Sekam & 0,009 \\
Moss & 0,010 \\
\hline
\end{tabular}

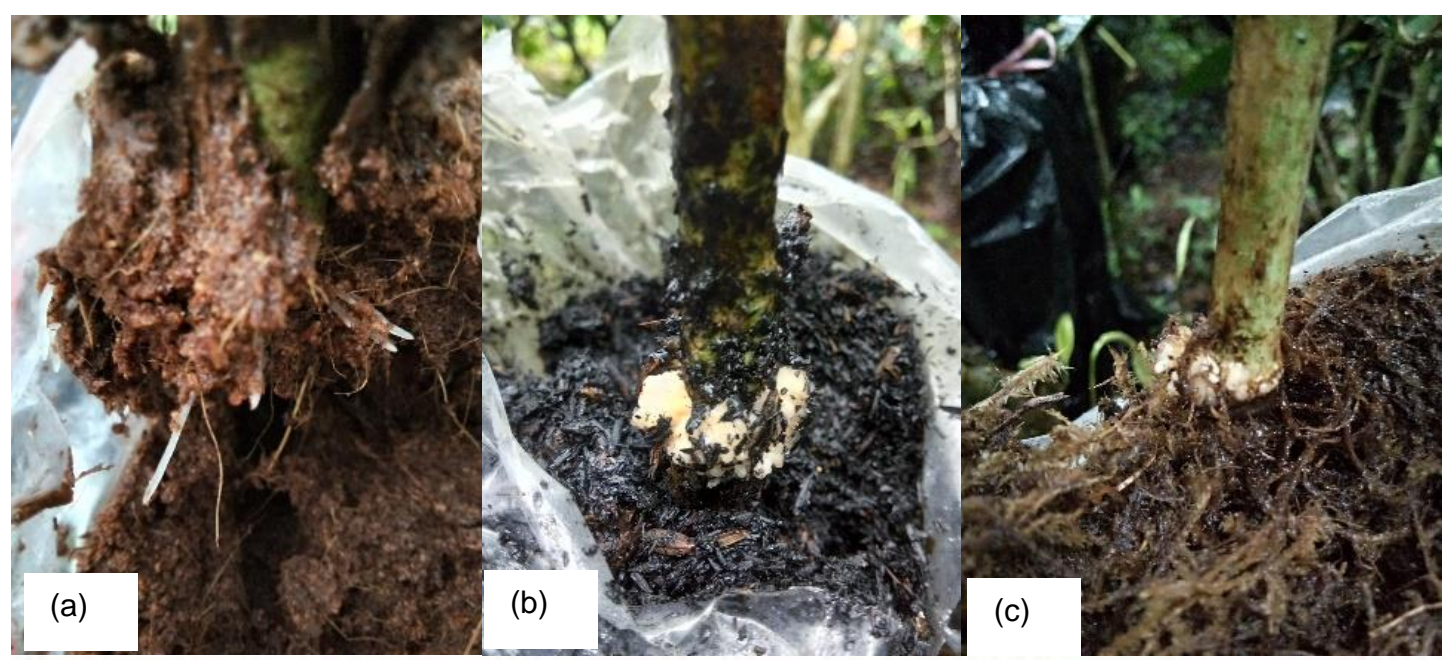

1234517131012345673320123456789301234567494012345874350

Gambar 2 Akar yang terbentuk pada 8 MSC (a) akar sepanjang $\pm 10 \mathrm{~cm}$ pada media serbuk sabut kelapa, (b) media arang sekam yang masih berupa bakal akar, dan (c) media moss yang masih berupa akar pendek $\pm 1 \mathrm{~cm}$. 


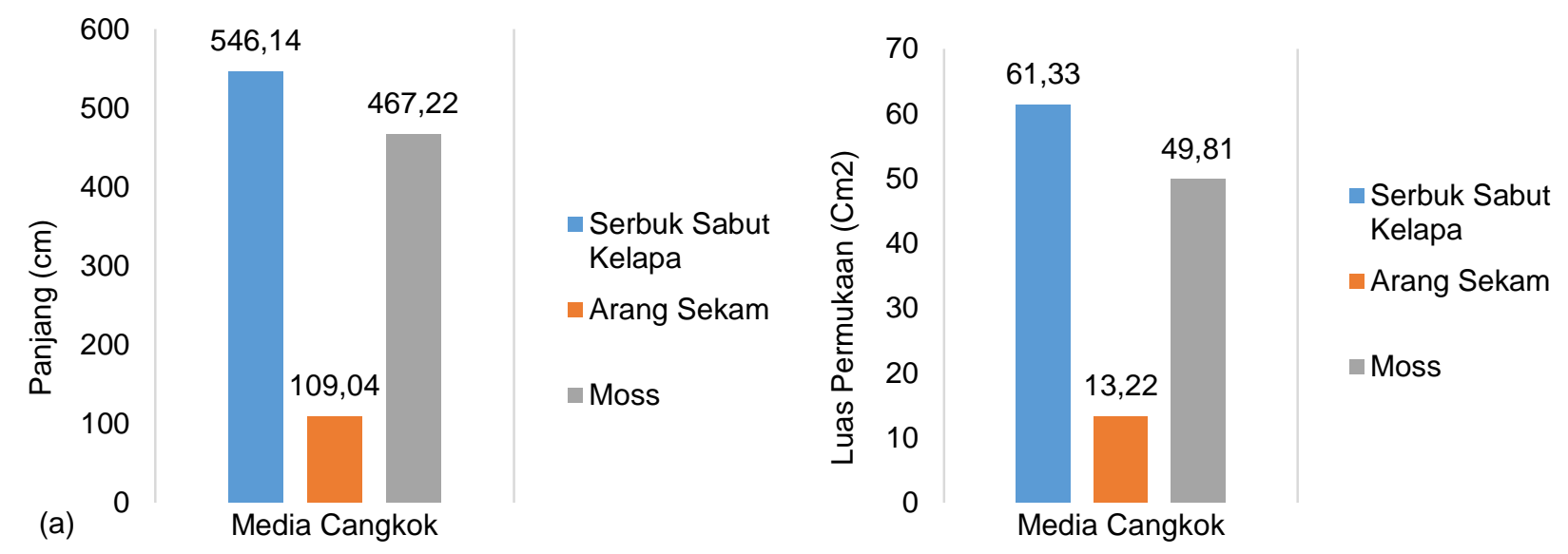

Gambar 3 a) Panjang akar dan b) Luas permukaan akar cangkok tanaman teh dengan menggunakan 3 jenis media (serbuk sabut kelapa, arang sekam, dan moss).

Tabel 5 Korelasi antara auksin dengan panjang dan luas permukaan akar cangkok pada tiga media

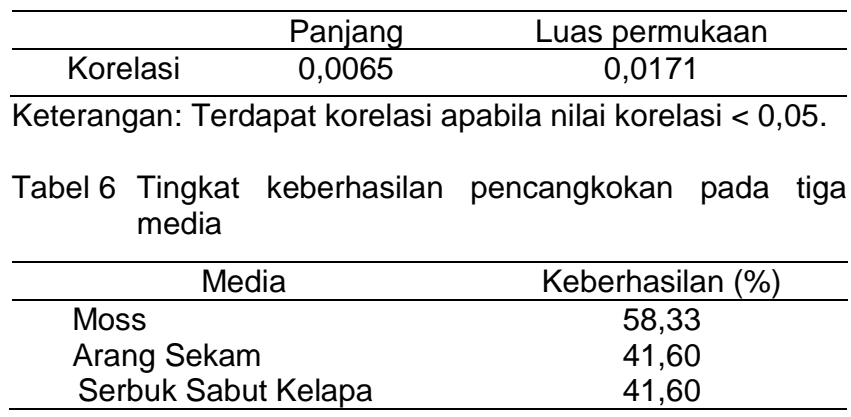

berkembang dengan leluasa. Media moss mampu mengikat air dengan baik serta memiliki drainase dan aerasi yang lancar sehingga memungkinkan akar tanaman tumbuh dan berkembang dengan leluasa. Serbuk sabut kelapa memiliki sifat sebaliknya, media serbuk sabut kelapa memiliki proporsi pori mikro cukup tinggi sehingga mampu menghambat gerakan air dan menyebabkan ketersediaan air lebih tinggi. Hasriani et al. (2013) menyatakan bahwa media tanam serbuk sabut kelapa memiliki kadar air dan daya simpan air masing-masing sebesar $119 \%$ dan $695,4 \%$. Pada saat tertentu, kondisi tersebut menyebabkan pertukaran gas pada media mengalami hambatan karena media mulai jenuh oleh air. Hal ini terjadi karena ruang pori makro yang seharusnya terisi oleh udara ikut terisi oleh air sehingga akar mengalami hambatan dalam pernapasan sehingga dapat menghambat pertumbuhan tanaman (Istomo \& Valentino 2012).

Hasil penelitian Prameswari et al. (2014) menunjukkan bahwa cangkokan dengan media moss menghasilkan kalus 2 minggu lebih cepat daripada media tanah + pupuk kandang yang baru membentuk kalus pada minggu keempat. Penggunaan moss menyebabkan air tetap tersedia bagi cangkokan sehingga pada fase awal proses perakaran, akar dapat tumbuh dan berkembang dengan baik sehingga proses pembentukan akar menjadi lebih cepat.

\section{KESIMPULAN}

Berdasarkan hasil dan pembahasan yang telah diuraikan maka dapat ditarik beberapa simpulan, yaitu media serbuk sabut kelapa, moss, dan arang sekam tidak berpengaruh secara nyata pada perkembangan morfologi akar cangkok dan karakter biokimia, yaitu kadar hormon auksin, giberelin, dan sitokinin. Tingkat keberhasilan pencangkokan tertinggi ditemukan pada moss 58,33\% sedikit berbeda dari media serbuk sabut kelapa dan arang sekam, yaitu $41,6 \%$. Sifat media unns memengaruhi keberhasilan pencangkokan

(b) ר kemampuan menyediakan ruang seimbang $\downarrow$ udara dan air yang mendukung kebutuhan

(b) nan menumbuhkan akar.

\section{DAFTAR PUSTAKA}

Arifin S. 2014. Gerakan Penyelamatan Agribisnis Teh Nasional (GPATN). Jakarta (ID): Dewan Teh Indonesia.

Ashari S. 2006. Hortikultura Aspek Budidaya. Jakarta (ID): UI Press.

Campbell NA, Reece JB. 2002. Biology. Sixth Edition, Pearson Education. Inc. San Francisco. 802-831.

Hasriani, Kalsim DK, Sukendro A. 2013. Kajian serbuk sabut kelapa (cocopeat) sebagai media tanam.

Hua Su Y, Bo Liu Y, Sheng Zhang X. 2011. Auxincytokinin interaction regulates meristem development. Molecular Plant. 4(4): 616-625. https://doi.org/10.1093/mp/ssr007 
Kementerian Pertanian. 2014. Perkembangan pasar teh Indonesia di pasar domestik dan pasar internasional tahun 2014. Jakarta (ID): Balai Penelitian Tanaman Industri dan Penyegar Kementerian Pertanian.

Mangoendidjojo W. 1993. Evaluasi beberapa nomer klon teh harapan di kebun pagilaran. Fakultas Pertanian Universitas Gadjah Mada. Yogyakarta (ID).

Mahfudloh A. 2008. Keberhasilan dan Pertumbuhan Stek Teh (Camellia sinensis (L) O Kuntze) Klon GMB 4 dan GMB 7 pada Beberapa Macam Media Tanam. IPB. Bogor (ID).

Miranda S. 2017. Efektivitas Serbuk sabut kelapa dan Arang Sekam dalam Mensubstitusi Media Tanam Rockwool pada Tanaman Mint (Mentha arvensis L.) secara Hidroponik dengan Sistem Sumbu. Artikel Ilmiah. Universitas Jambi.

Miyashita T, Takafumi O, Fukashi S, Hajime A, Yoichiro H. 2009. Plant regeneration with maintenance of the endosperm ploidy level by endosperm culture in lonicera caerulea var. emphyllocalyx. Plant Cell Tissue and Organ Culture (98): 291-301. https:// doi.org/10.1007/s11240-009-9562-6
Mumpuni R. 2008. Pengelolaan Pemupukan pada Tanaman Teh (Camellia sinensis (L.) O. Kuntze) di PT. Pagilaran, Batang, Jawa Tengah. Institut Pertanian Bogor. Bogor (ID).

Prameswari ZK, Trisnowati S, Waluyo S. 2014. Pengaruh Macam Media dan Zat Pengatur Tumbuh Terhadap Keberhasilan Cangkok Sawo (Manilkara zapota (L.) van Royen) pada Musim Penghujan. Vegetalika. 3(4): 107-118.

Salisbury FB, Ross CW. 1995. Fisiologi tumbuhan jilid 2. Bandung (ID): ITB Press.

Samudin S. 2009. Pengaruh kombinasi auksinsitokinin terhadap pertumbuhan buah naga. Media Litbang Sulteng. 2(1): 62-66.

Sulasiah A, Christiani T, Tuti L. 2015. Pengaruh pemberian jenis dan konsentrasi auksin terhadap induksi perakaran pada tunas Dendrobium sp. secara in vitro. Bioma. 11(1): 56-66. https:// doi.org/10.21009/Bioma11(2).5

Widyastuti N, Donowati T. 2007. Peranan beberapa zat pengatur tumbuh (ZPT) tanaman pada kultur in vitro. Jurnal Sains dan Teknologi Indonesia. 3(5): 55-63. 